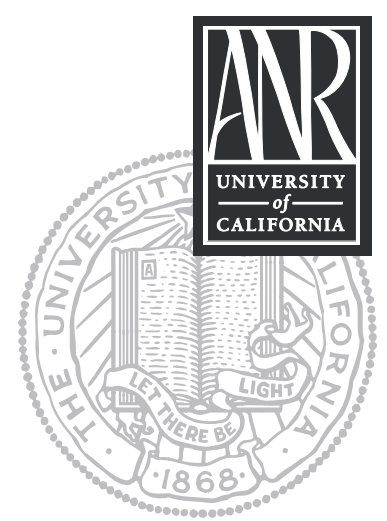

UNIVERSITY OF CALIFORNIA

Division of Agriculture and Natural Resources http://anrcatalog.ucdavis.edu

This document describes opportunities for dairy producers to use feed management to reduce nutrient levels in manure produced at their dairy.

\title{
Use of Feed Inventory Records to Reduce Nutrient Loading at Dairy Operations: Producer Options
}

DEANNE MEYER, Livestock Waste Management Specialist, Department of Animal Science, University of California, Davis; PETER ROBINSON, Dairy Cattle Nutritionist, University of California, Davis

\section{OVERVIEW OF FEED MANAGEMENT}

A key objective of feed management is to provide the nutrients necessary to achieve animal performance objectives while minimizing the environmental impact of nutrients excreted in manure. For recommendations for concentrations of nutrients in diets, see table 1.

Most software programs used to formulate diets at dairies aim to provide minimum required concentrations of nutrients for the least cost. Few software programs identify maximum nutrient concentrations or impose constraints to prevent overfeeding of nutrients. Overfeeding of nutrients can occur when diets are properly formulated yet rations are not mixed correctly.

Overfeeding nutrients can increase costs for manure management and can be economically devastating where limited land is available for manure nutrient application. Maintaining feed records and analyzing production data helps dairy operators identify ways to reduce nutrient excretion, which reduces costs related to manure management and allows operators to better estimate the land required for application of specific nutrients.

Alternative methods for managing manure are increasing manure exports, increasing the amount of cropland for manure application, and reducing herd size.

\section{Table 1. Recommended nutrient content of diets for dairy cattle}

\begin{tabular}{|c|c|c|c|c|c|c|c|}
\hline \multicolumn{6}{|c|}{ Lactating cow diets } & $\begin{array}{l}\text { Early lactation } \\
\text { (weeks } 0 \text { to } 3 \text { ) }\end{array}$ & $\begin{array}{l}\text { Dry pregnant } \\
\text { cows }\end{array}$ \\
\hline $\begin{array}{l}\text { Cow weight } \\
\text { (lb) }\end{array}$ & Fat (\%) & $\begin{array}{l}\text { Weight gain } \\
\text { (Ib/day) }\end{array}$ & \multicolumn{3}{|c|}{ Milk yield (lb/day) } & & \\
\hline 900 & 5.0 & 0.50 & 43 & 58 & 74 & & \\
\hline 1,100 & 4.5 & 0.60 & 55 & 73 & 91 & & \\
\hline 1,300 & 4.0 & 0.72 & 70 & 93 & 117 & & \\
\hline 1,500 & 3.5 & 0.82 & 78 & 104 & 130 & & \\
\hline 1,700 & 3.5 & 0.94 & 86 & 114 & 143 & & \\
\hline \multicolumn{3}{|c|}{ Protein equivalent } & \multicolumn{5}{|c|}{ Percentage of diet dry matter } \\
\hline \multicolumn{3}{|c|}{ crude protein (\%) } & 16 & 17 & 18 & 19 & 12 \\
\hline \multicolumn{3}{|c|}{ undegradable intake protein (\%) } & 5.7 & 6 & 6.3 & 7.2 & \\
\hline \multicolumn{3}{|c|}{ degradable intake protein (\%) } & 9.7 & 10.4 & 10.4 & 9.7 & \\
\hline \multicolumn{3}{|l|}{ Minerals } & \multicolumn{5}{|c|}{ Percentage of diet dry matter } \\
\hline \multicolumn{3}{|l|}{ calcium } & 0.60 & 0.65 & 0.66 & 0.77 & 0.39 \\
\hline \multicolumn{3}{|l|}{ phosphorus } & 0.38 & 0.42 & 0.41 & 0.49 & 0.24 \\
\hline \multicolumn{3}{|l|}{ magnesium } & 0.20 & 0.25 & 0.25 & 0.25 & 0.16 \\
\hline \multicolumn{3}{|l|}{ potassium } & 0.90 & 1.00 & 1.00 & 1.00 & 0.65 \\
\hline \multicolumn{3}{|l|}{ sodium } & 0.18 & 0.18 & 0.18 & 0.18 & 0.10 \\
\hline \multicolumn{3}{|l|}{ chlorine } & 0.25 & 0.25 & 0.25 & 0.25 & 0.20 \\
\hline
\end{tabular}

Source: NRC 1989, appendix table 5 (due to lack of similar table in NRC 2001). 
The Central Valley Regional Water Quality Control Board has developed a preliminary facility dairy assessment process that compares estimated nutrients available for land application (basically those nutrients excreted in manure and imported as fertilizer) to estimated nutrients exported offsite in manure or removed by crops grown at each dairy. When a preliminary dairy facility assessment indicates that nutrients present exceed nutrients needed by crops, feed management should be evaluated to determine if nutrient excretion can be reduced. Although the first sets of calculations will focus on nitrogen $(\mathrm{N})$, phosphorus $(\mathrm{P})$ and potassium $(\mathrm{K})$, subsequent analyses will evaluate salt.

\section{CONVERTING NUTRIENTS TO PRODUCTS}

Animal type, feed quality, feed storage and mixing practices, and frequency of feeding contribute to the efficiency by which nutrients in feed are converted to animal products. For example, incorporation of feed nutrients to animal products is lowest by growing heifers and dry cows and highest by lactating animals. Since the proportions of cattle at various stages of growth vary among facilities, maximum nutrient conversion values vary by facility.

\section{Feed Processing}

Feed processing can alter the availability of nutrients. For example, the starch in steamflaked corn is more digestible than the starch in dry-cracked corn. Because rumen microbes can more efficiently convert feed into absorbable nutrients when their carbohydrate needs are met, microbes in the rumen of cattle fed steam-flaked corn may be more efficient at converting feed nutrients into absorbable nutrients than they are at converting other starch sources, increasing efficiency of nutrient use.

Another example is feeding by-products from ethanol production. An ethanol plant using corn feedstock yields ethanol and distiller's grains ("distillers"). Distillers are nutrient-dense compared to the original corn grain. When substituting distillers for corn in an animal diet, other ingredients should be modified to maintain NRC recommendations. If corn is replaced 1:1 with distillers, the manure will have higher amounts of nitrogen, phosphorus, and other nutrients.

\section{Ensiling}

Ensiling forages encourages rapid fermentation and preservation of forage. To help minimize protein degradation and conserve nitrogen in feed, silage containers should be filled quickly, packed densely, and covered immediately.

The form of certain nutrients alters their bioavailability to animals. When a feed has relatively low bioavailability of a nutrient, a relatively greater quantity must be fed to supply a specific bioavailable amount of the nutrient. This results in more of the nutrient being excreted by the animal.

\section{FORMULATING DIETS FOR DAIRY COWS}

Diets for dairy cows are formulated based on the assumed nutrient concentrations in feeds required to achieve good animal health while producing a saleable product. It is important that the assumed values for forages be obtained from actual forage analysis. A recent study conducted by the authors (Feed nutrient management on dairy farms: an essential component of a CNMP. California State Water Resources Control Board Contract No. 2-037-250-0) showed that more than 50 percent of the nitrogen, phosphorus, and potassium fed at eight California dairies was consumed in the form of forages (table 2). Thus, it is critical to analyze each forage and use the analytical results when formulating diets. 
Table 2. Contribution of feed categories to total nutrient inputs

\begin{tabular}{|c|c|c|c|c|c|c|c|}
\hline \multirow[b]{2}{*}{ Feed category } & $\mathrm{N}$ & $\mathrm{Ca}$ & $\mathbf{P}$ & K & $\mathrm{Mg}$ & $\mathrm{Na}$ & $\mathrm{Cl}-$ \\
\hline & \multicolumn{7}{|c|}{ Percent of total intake of nutrient from feed } \\
\hline forages & 68.03 & 75.17 & 50.18 & 62.41 & 60.75 & 26.12 & 69.51 \\
\hline plant by-products & 3.89 & 4.64 & 3.05 & 14.75 & 3.61 & 2.39 & 0.70 \\
\hline grains & 8.52 & 0.65 & 14.38 & 3.88 & 4.35 & 1.37 & 3.84 \\
\hline protein meals & 11.31 & 1.39 & 8.41 & 5.51 & 2.62 & 0.39 & 0.59 \\
\hline whole seeds & 6.08 & 2.24 & 9.53 & 6.43 & 5.11 & 0.89 & 1.50 \\
\hline miscellaneous & 0.15 & 0.01 & 0.13 & 0.04 & 0.03 & 0.25 & 0.93 \\
\hline minerals and vitamins & 0.00 & 0.42 & 0.00 & 0.00 & 0.00 & 11.55 & 13.50 \\
\hline additional supplements & 0.12 & 14.57 & 12.52 & 1.59 & 22.65 & 56.39 & 5.51 \\
\hline bedding & 1.91 & 0.92 & 1.79 & 5.37 & 0.87 & 0.63 & 3.94 \\
\hline
\end{tabular}

Although it is very important to analyze forages for all nutrients, most other feedstocks are likely to be critical only for specific nutrients and thus do not need as frequent chemical analyses. Currently, nitrogen, phosphorus, and potassium are the most important nutrients.

\section{Feed Ingredient Analyses}

There are two key factors for determining when a particular feedstuff needs to be analyzed: First, how variable is the nutrient content of the feed? Second, how much of the dietary nutrients are provided by the feed? If the nutrient analysis of a feed ingredient is highly variable, the feed should be analyzed if the ingredient constitutes more than 10 percent of any given nutrient fed at the dairy. If the feed ingredient is not highly variable, a reference value may be sufficient.

\section{Feed supplies}

Mixing rations requires that ingredients must be available. When a feed bay is empty, the feeder may replace the missing ingredient with something else, altering the nutrient quantities fed to animals and influencing nutrient excretion. To maintain optimal diets, schedule feed deliveries to ensure availability.

\section{Shrink}

Shrink is the loss of feed through processing or relocation at the facility, including spill-

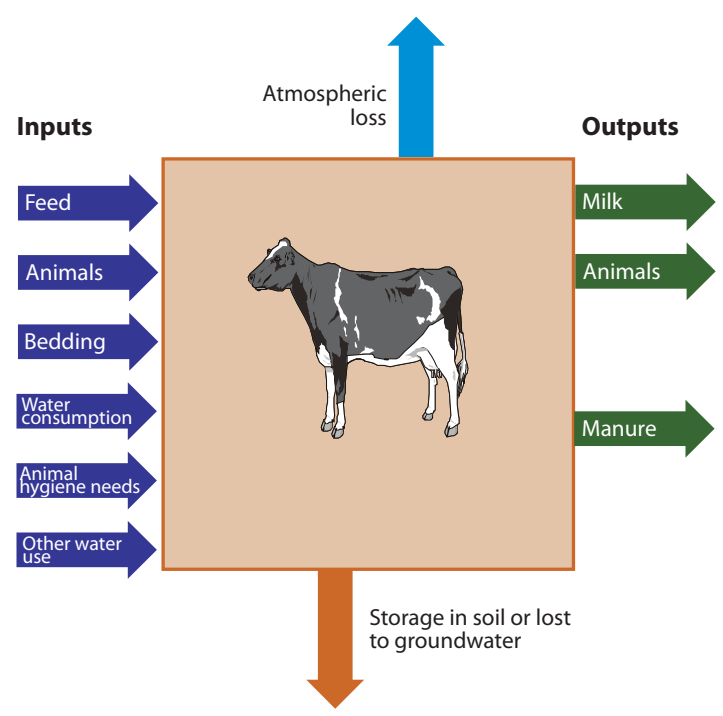

Figure 1. Production facility nutrient balance parameters. age. Feed shrink greater than 5 percent should be both a financial and an environmental concern. Reducing shrink increases nutrient efficiency for the production facility.

\section{Uneaten or spoiled feed}

Uneaten or spoiled feed represents another feed inefficiency with potential adverse environmental impacts. Manage feeding frequency and quantity to minimize uneaten feed. Also, manage moist feed ingredients and mixed feeds to minimize spoilage.

\section{Production facility nutrient balance analysis}

A production facility nutrient balance analysis evaluates nutrients, such as nitrogen, phosphorus, and potassium, entering a dairy, primarily in feeds, and exiting the dairy as managed outputs, primarily in milk (fig. 1). The nutrient balance quantifies all nutrients, including nutrients imported in materials such as purchased bedding. To conduct a 
nutrient balance assessment, it is necessary to have adequate records, including data for purchased feeds and analytical results for forages, bedding materials, and so on that contain nutrients.

\section{Efficiency of nutrient conversion}

Nutrients consumed by the animal that are not converted into product must be handled to minimize the impact on the environment. Ideally, "designer manure" could be developed by manipulation of dietary ingredients so that the excreted nutrients more closely match the nutrients needed for crop production. Nutrient levels in manure are related to the efficiency of incorporating nutrients in products. The efficiency of incorporation of selected nutrients in seven commercial dairies in California is presented in table 3.

These data are provided for comparison purposes only.

\section{Nutrient Efficiency versus Cropland}

As nutrient efficiency increases, less nutrients are excreted in manure and less cropland is needed to use the manure. Changes in nutrient efficiencies can be used to evaluate land needs for manure application when feed efficiencies are increased.

As an example for cropland needs controlled by nitrogen applications, consider a dairy that incorporates 16 percent of $\mathrm{N}$ fed into animal product; for every 1,000 pounds of $\mathrm{N}$ fed, 840 pounds of $\mathrm{N}$ are excreted. If the dairy increases incorporation of $\mathrm{N}$ to 27 percent of $\mathrm{N}$ fed, then 730 pounds of $\mathrm{N}$ are excreted. The difference of 110 pounds means that 15 percent less land would be needed for nitrogen recycling at the more efficient facility. An alternate way of looking at the situation is to say 15 percent more cows can be milked at the more efficient facility.

If an element other than nitrogen limited land application of manure, analysis of the particular element would be important. The additional land needed for the lowest-efficiency facility compared to the highest-efficiency facility is presented (expressed as a percent) at the bottom of table 3. The data show that there can be a tremendous opportunity to reduce cropland needs. For example, where phosphorus is the controlling nutrient, the facility where the efficiency was lowest (22 percent conversion) needed 27 percent more land than the facility where phosphorus efficiency is highest.

When formulated diets and fed rations for a herd exceed NRC guidelines, the efficiency of incorporating feed nutrients into the herd can be improved. Great potential exists for improving incorporation of sodium $(\mathrm{Na})$, chlorine $\left(\mathrm{Cl}^{-}\right)$, and calcium $(\mathrm{Ca})$ where the increases in land needed for nutrient application were 102, 50, and 26 percent, respectively, between highest and lowest nutrient incorporation efficiency. Incorporation of sodium and chlorine into animal products was variable and highly dependent on the method of feeding of salt and supplements. For sodium, the herd that was most efficient

Table 3. Efficiency of incorporation of nutrients into animal product

\begin{tabular}{|l|l|l|l|l|l|l|l|l|}
\hline & \multicolumn{7}{|c|}{ Grams incorporated / grams consumed } \\
\hline Herd & $\mathbf{N}$ & $\mathbf{C a}$ & $\mathbf{P}$ & $\mathbf{K}$ & $\mathbf{M g}$ & $\mathbf{N a}$ & $\mathbf{C l}$ \\
\hline 1 & 0.18 & 0.32 & 0.21 & 0.14 & 0.04 & 0.55 & 0.38 \\
\hline 2 & 0.27 & 0.15 & 0.29 & 0.10 & 0.03 & 0.06 & 0.14 \\
\hline 3 & 0.26 & 0.25 & 0.38 & 0.11 & 0.05 & 0.39 & 0.42 \\
\hline 4 & 0.21 & 0.15 & 0.29 & 0.10 & 0.04 & 0.09 & 0.13 \\
\hline 5 & 0.16 & 0.14 & 0.26 & 0.09 & 0.02 & 0.12 & 0.19 \\
\hline 6 & 0.21 & 0.14 & 0.22 & 0.10 & 0.03 & 0.11 & 0.18 \\
\hline 7 & 0.27 & 0.20 & 0.33 & 0.07 & 0.04 & 0.13 & 0.30 \\
\hline & Additional land needed (percent) between least and most efficient operation if land application \\
\hline
\end{tabular}


(55 percent incorporated into animal product) did not supplement a sodium-based buffer, nor did it use salt in the total mixed ration. Salt was only fed free choice. Although it is unlikely that land application of manure will be restricted based on sodium amounts, it is important to recognize that feeding unused nutrients impacts the overall salt balance for the facility and will contribute to buildup of salts in soil or underlying groundwater.

The data suggest that little opportunity exists to significantly reduce excretion of potassium or magnesium $(\mathrm{Mg})$. Incorporation data for potassium were 14 percent (high efficiency) and 7 percent (low efficiency). Although one value is 100 percent greater than the other, the difference in the land needed is minimal. For 1,000 pounds of $\mathrm{K}$ fed to animals, 860 pounds of $\mathrm{K}$ would be excreted in the high-efficiency herd, and 930 pounds would be excreted in the low-efficiency herd. The difference is 70 pounds ( 8 percent).

In areas where salt management is a concern, it is also important to evaluate water use and the contribution of water used for drinking, udder hygiene, and cow cooling to the salt load in the manure stream.

\section{FEED MANAGEMENT DO'S}

Many actions can be taken to minimize excretion and accumulation of nutrients at any dairy. The following actions are recommended.

- Work with your nutritionist to be sure you are feeding diets with nutrient densities near NRC recommended levels for protein, phosphorus, potassium, and salts.

- Create a historical library of analyses of feed and manure.

- Check that the feedstuffs needed for the formulated diets are actually present in sufficient quantity.

- Analyze incoming feeds, especially forages, for key nutrients and use that information in diet formulation.

- Evaluate the use of feed supplements (buffers, minerals, and vitamins) and their impact on the nutrient content of manure; seasonally reevaluate inclusion of all dietary supplements.

- Monitor feed management to minimize waste and spoiled feeds.

- Evaluate salt concentrations in feeds and avoid using feeds that contribute excessive salts or undesired salts to manure.

- Carefully evaluate the use of free choice or block salt when salt is included in total mixed rations.

- Analyze nondrinking water use if salts are elevated in water and are a concern in manure. Be sure to not jeopardize animal well being or water quality in the process.

\section{REFERENCES}

NRC (National Research Council). 1989. Nutrient requirements of dairy cattle. 6th rev. ed. Washington, DC: National Academy Press.

- 2001. Nutrient requirements of dairy cattle. 7th ed. Washington, DC: National Academy Press.

\section{METRIC EQUIVALENTS}

\begin{tabular}{|l|c|c|c|}
\hline English & $\begin{array}{c}\text { Conversion factor for } \\
\text { English to Metric }\end{array}$ & $\begin{array}{c}\text { Conversion factor for } \\
\text { Metric to English }\end{array}$ & Metric \\
\hline acre (ac) & 0.4047 & 2.47 & hectare (ha) \\
\hline pound (lb) & 0.454 & 2.205 & kilogram (kg) \\
\hline pound per acre (lb/ac) & 1.12 & 0.89 & $\begin{array}{c}\text { kilogram per hectare } \\
\text { (kg/ha) }\end{array}$ \\
\hline
\end{tabular}




\section{FOR FURTHER INFORMATION}

A companion publication is available for dairy nutritionists: Dairy Nutritionists' Roles in Nutrient Use: Recommendations for Feed Nutrient Records Analyses (ANR Publication 8278, http://anrcatalog.ucdavis.edu/pdf/8278.pdf).

To order or obtain ANR publications and other products, visit the ANR Communication Services online catalog at http://anrcatalog.ucdavis.edu or phone 1-800-994-8849. You can also place orders by mail or FAX, or request a printed catalog of our products from

University of California

Agriculture and Natural Resources

Communication Services

6701 San Pablo Avenue, 2nd Floor

Oakland, California 94608-1239

Telephone: (800) 994-8849 or (510) 642-2431

FAX: (510) 643-5470

E-mail inquiries: danrcs@ucdavis.edu

This publication has been anonymously peer reviewed for technical accuracy by University of California scientists and other qualified professionals. This review process was managed by the ANR Associate Editor for Animal, Avian, and Aquaculture Sciences.

Publication 8277

ISBN-13: 978-1-60107-514-7

(C)2007 The Regents of the University of California

Division of Agriculture and Natural Resources

All rights reserved.

No part of this publication may be reproduced, stored in a retrieval system, or transmitted, in any form or by any means, electronic, mechanical, photocopying, recording, or otherwise, without the written permission of the publisher and the authors.

The University of California prohibits discrimination or harassment of any person on the basis of race, color, national origin, religion, sex, gender identity, pregnancy (including childbirth, and medical conditions related to pregnancy or childbirth), physical or mental disability, medical condition (cancer-related or genetic characteristics), ancestry, marital status, age, sexual orientation, citizenship, or status as a covered veteran (covered veterans are special disabled veterans, recently separated veterans, Vietnam era veterans, or any other veterans who served on active duty during a war or in a campaign or expedition for which a campaign badge has been authorized) in any of its programs or activities. University policy is intended to be consistent with the provisions of applicable State and Federal laws.

Inquiries regarding the University's nondiscrimination policies may be directed to the Affirmative Action/Staff Personnel Services Director, University of California, Agriculture and Natural Resources, 1111 Franklin Street, $6^{\text {th }}$ Floor, Oakland, CA 94607-5201, (510) 987-0096. For information about ordering this publication, telephone 1-800-994-8849.

pr-10/07-SB/CM 